\title{
Correction to: Alignments between strategic content and process structure: the case of container terminal service process automation
}

\author{
Ping Wang ${ }^{1} \cdot$ Joan P. Mileski $^{1} \cdot$ Qingcheng Zeng ${ }^{2}$
}

Published online: 22 February 2018

(C) The Author(s) 2019

\section{Correction to: Marit Econ Logist https://doi.org/10.1057/s41278-017-0070-z}

We regret that one of the author's names (Qingcheng Zeng) was misspelt in the original version of the article and the order in which the authors appeared was incorrect. The original article stated the authors as follows:

Joan P. Mileski, Ping Wang and Qingchen Zeng

We apologise for this oversight but would like to reassure readers that no aspect of the research itself is under question.

The original article has been corrected.

Open Access This article is distributed under the terms of the Creative Commons Attribution 4.0 International License (http://creativecommons.org/licenses/by/4.0/), which permits unrestricted use, distribution, and reproduction in any medium, provided you give appropriate credit to the original author(s) and the source, provide a link to the Creative Commons license, and indicate if changes were made.

The original article can be found online at https://doi.org/10.1057/s41278-017-0070-z.

Ping Wang

wangp@tamug.edu

Joan P. Mileski

mileskij@tamug.edu

1 Department of Maritime Administration, Texas A\&M University, Galveston Campus, 200

Seawolf Parkway, Galveston, TX 77554, USA

2 Department of Management Science, College of Transportation Management, Dalian Maritime University, Dalian, People's Republic of China 